\author{
Joanna Małocha \\ http://orcid.org/0000-0001-6965-4297 \\ Uniwersytet Papieski Jana Pawła II w Krakowie \\ joanna.malocha@upip2.edu.pl \\ DOI: $10.35765 /$ pk.2021.3201.03
}

\title{
Historia religijnego tatuażu koptyjskiego i jego znaczenie w kręgu kulturowym chrześcijan egipskich
}

\section{STRESZCZENIE}

Pomimo znacznego ogólnoświatowego zainteresowania sytuacją polityczną na Bliskim Wschodzie stopień znajomości tradycji koptyjskiej wśród humanistów środkowoeuropejskich nadal uznać należy za niewystarczający. Niniejsze rozważania stanowią zatem próbę choć cząstkowego zapełnienia tej luki poprzez analizę specyficznego zjawiska tatuażu religijnego, od wieków do dzisiaj występującego w środowisku chrześcijan egipskich. Przy czym wprowadzenie - umożliwiające lepsze zrozumienie tego fenomenu - stanowi krótka charakterystyka etnosu koptyjskiego oraz omówienie wybranych aspektów ogólnej historii tatuażu, związanych z prezentowanym tematem (tj. jego obecności w klasycznej kulturze starożytnego Egiptu oraz ulegającego z czasem przemianom stosunku hierarchii kościelnej do tego typu zdobień ciała). Natomiast zasadnicza część artykułu poświęcona została trzem zagadnieniom szczegółowym: okolicznościom wykonywania rzeczonych tatuaży (dawniej jako znaku stygmatyzującego, obecnie - towarzyszącego ważnym momentom życiowym; $\mathrm{z}$ uwzględnieniem różnicy technik stosowanych w Górnym Egipcie i diasporze jerozolimskiej), najpopularniejszym wzorom (od najprostszych i niewielkich krzyży koptyjskich po pełnopostaciowe przedstawienia scen ewangelicznych i wizerunków świętych) oraz funkcji, jaką pełnił dawniej i pełni obecnie koptyjski tatuaż religijny (od piętnującej przez magiczno-wyznaniową i socjalną po psychologiczną).

SŁOWA KLUCZE: Koptowie, Egipt, funkcja tatuażu, tatuaż religijny, Razzouk 


\section{ABSTRACT}

The History of Coptic Religious Tattoo and its Significance in the Cultural Circle of Egyptian Christians

Despite considerable global interest in the political situation in the Middle East, the knowledge of Coptic traditions among Central European humanists remains insufficient. The present paper is an attempt at filling, at least partially, that gap by analysing a specific phenomenon of religious tattoo, which has been present in the community of Egyptian Christians for ages. The introduction, aimed at facilitating a better understanding of this phenomenon, consists of a short characteristic of Coptic ethnos and a review of chosen aspects of tattoo's history connected with the presented topic (i.e. its presence in the classical culture of Ancient Egypt and gradual shift in the approach of ecclesiastical hierarchy towards this kind of body art). The main part of the article is devoted to three specific issues: circumstances accompanying the process of tattoo making (in the past as a stigma, nowadays as a sign accompanying important life events; with a mention of a difference in techniques used in Upper Egypt and the Jerusalem diaspora), the most common patterns (from the simplest little Coptic crosses to full person illustrations of evangelical scenes and images of saints) as well as the function which the Coptic religious tattoo used to serve in the past, and serves now (from stigmatizing through magical-religious and social up to psychological).

KEYWORD S : Copts, Egypt, tattoo function, religious tattoo, Razzouk

\section{Wstęp}

W marcu 2012 r. liczne internetowe portale informacyjne podały alarmującą wiadomość o śmierci papieża. W zachodnim kręgu kulturowym budziło to jednoznaczne skojarzenie z osobą biskupa Rzymu. I dopiero bliższa lektura odnośnych artykułów wyjaśniała czytelnikom, iż chodzi o Shenoudę III noszącego zwyczajowy tytuł Papieża Aleksandrii i od ponad 40 lat piastującego urząd Patriarchy Koptyjskiego Kościoła Ortodoksyjnego. To właśnie w tego typu okolicznościach Egipt i mniejszościowa społeczność tamtejszych chrześcijan zwraca na siebie uwagę świata. Z reguły jednak przeciętny Europejczyk - nierzadko nawet ten posiadający wykształcenie humanistyczne nie dysponuje bardziej precyzyjną wiedzą o specyfice, tradycji i historii Koptów (Hamilton, 2006). Stąd też niniejszy artykuł stanowi próbę przybliżenia wybranego, a jednocześnie dość charakterystycznego aspektu tejże tradycji zwyczaju wykonywania koptyjskich tatuaży religijnych.

Przy czym, dla lepszego zrozumienia tego fenomenu, rozpoczęto od krótkiej charakterystyki etnosu koptyjskiego oraz omówienia wybranych 
aspektów ogólnej historii tatuażu związanych z prezentowanym tematem. Natomiast w zasadniczej partii tekstu autorka skupiła się na dawnych i współczesnych okolicznościach oraz sposobach jego wykonywania, walorach estetyczno-stylistycznych, a wreszcie - funkcji, jaką pełnił pierwotnie i pełni obecnie w środowisku Koptów.

\section{Specyfika cywilizacji koptyjskiej jako pokłosie przeszłości narodu}

W 30 r. a.Ch. Egipt został wcielony do państwa rzymskiego jako prywatna posiadłość cesarska. Dla tamtejszej ludności autochtonicznej - potomków Egipcjan epoki dynastycznej - przejście spod władzy macedońskiej pod rzymską było jednak zabiegiem jedynie kosmetycznym i niewiele zmieniło. Bowiem według prawodawstwa nowego okupanta owa najliczniejsza grupa społeczna w prowincji była tylko deidici, tj. własnością cesarza. Egipcjanie do niej należący nie mieli zatem szans na osiąnnięcie statusu obywatela i awansu społecznego. Oni też - jako jedyni w Imperium - tracili uprawnienia czasowo nabywane podczas służby w armii rzymskiej, przy czym i tak z reguły wcielani byli najwyżej jako wioślarze do załóg statków wojennych. Możliwe były dla nich do zdobycia jedynie najniższe stopnie administracji, tj. sołtysa i wiejskiego pisarza - a zatem te, które wymagały dobrej znajomości specyfiki miejscowej gospodarki rolnej (zwłaszcza działania systemu kanałów irygacyjnych). Co zatem zrozumiałe, w większości zamieszkiwali osiedla o charakterze wiejskim.

Inaczej wyglądała sytuacja - szeroko rozumianej - ludności greckiej, obecnej w Egipcie w większej liczbie od czasów ptolemejskich. Jej członkowie uważani byli bowiem za foederati, tj. sprzymierzonych. Posiadali oni własne prawo, zamieszkiwali głównie miasta i znaczniejsze osady. Dumnie reprezentowali też swą spuściznę artystyczną i filozoficzną. Nad tymi dwiema warstwami społecznymi znajdowała się jeszcze nieliczna grupka Rzymian, z reguły wysyłanych z serca Imperium celem objęcia najwyższych stanowisk w prowincji (Wessel, 1966).

Nie dziwi więc fakt, iż od III w. mnożyły się świadectwa ostrej nienawiści uciskanych Egipcjan, zarówno w stosunku do Greków, jak i do Rzymian. Im większa zaś była ich niechęć wobec kultury hellenistycznej i religii okupanta, tym gorliwiej ludność autochtoniczna przyjmowała chrześcijaństwo głoszące zasadę, iż „ostatni będą pierwszymi” (Mt 20,16). Z nieukrywaną dumą Egipcjanie podkreślali, że ich ziemia dała schronienie Dziecięciu przed gniewem Heroda (Mt 2,13-15.19-21; por Oz 11,1), zaś początki Kościoła egipskiego łączono $-\mathrm{z}$ historycznie niepotwierdzoną, za to silnie 
zakorzenioną - tradycją działalności misyjnej w Aleksandrii św. Marka Apostoła (Atiya, 1978; Kamil, 1987) ${ }^{1}$. Z czasem zatem wrogość narodowościowa połączyła się także z niesnaskami wyznaniowymi. Przy czym szczególnie krwawe żniwo przyniosło w Egipcie ostatnie wielkie prześladowanie chrześcijan, wywołane edyktami Galeriusza i Dioklecjalna. Skalę ilości ofiar, jakie rozporządzenia te pociagnęły za sobą, oddaje fakt, iż rok 284 (tj. data wstąpienia na tron Dioklecjana) stał się dla egipskich chrześcijan początkiem nowego systemu chronologicznego - tzw. Ery Męczenników (Kamil, 1987).

Mimo tak trudnych realiów to w łonie Kościoła koptyjskiego powstała na przełomie II i III stulecia największa szkoła katechetyczna starożytności, w której nauczały tak wybitne postaci jak Klemens Aleksandryjski (150215) i Orygenes (185-254). Niemal równolegle na egipskiej pustyni zrodziło się życie monastyczne w dwóch swych podstawowych odmianach: anachoretyzmie, ze sztandarową postacią św. Antoniego Pustelnika (251-356), oraz cenobityzmie, za którego twórcę uchodzi św. Pachomiusz (292-347) (Atiya, 1978; Desprez, 1999; Draguet, 1949; Drączkowski, 1998; Kamil, 1987; Lefort, 1943; Meinardus, 1961; 2002; Michalski, 1975). Jednocześnie z Aleksandrią związane były też dwie wielkie herezje, które wstrząsnęły Kościołem pierwszych wieków: arianizm, negujący bóstwo Chrystusa, i nestorianizm, podający w wątpliwość charakter relacji pomiędzy ludzką i boską naturą Zbawiciela oraz rangę Maryi jako Bogurodzicy (Theotokos). W wyniku tego ostatniego sporu główny, ortodoksyjny nurt Kościoła koptyjskiego odrzucił postanowienia Soboru Chalcedońskiego (451 r.) i uznawany jest za monofizycki, a zatem nie pozostaje w jedności z Rzymem².

W momencie więc, gdy w 646 r. wyznawcy Allacha opanowali Aleksandrię, wybitna większość Egipcjan była wyznania chrześcijańskiego. Stąd też islamski najeźdźca postawił eponimiczny znak równości między nazwą hellenistycznej prowincji Aigyptos a jej mieszkańcami, rozumianymi jako religijnie jednolita chrześcijańska społeczność. Ludność tę w zarabizowanej wersji zaczęto określać mianem qubt, czyli po polsku

1 O stopniu wagi, jaką Koptowie przywiązują do tego wątku ewangelicznej historii - zazwyczaj umniejszanego z europejskiej perspektywy - świadczy fakt, iż w Egipcie do dzisiaj publikowane są szczegółowe opisy sanktuariów i miejsc kultu powstałych nad Nilem na trasie, którą według tradycji miała przemierzyć Święta Rodzina (Farid, 1965; Meinardus, 1963; 2002; Lambelet, 1993).

2 Częste stawianie znaku równości między chrześcijaństwem koptyjskim a wywodzącym się z Konstantynopola eutychianizmem stanowi jednak zbytnie uproszczenie o wiele bardziej skomplikowanego zagadnienia teologicznego. Sami Koptowie jasno przedstawiają swoją doktrynę o dwóch naturach Zbawiciela mistycznie połączonych w jedną, ale bez pomieszania, zlania się czy zmiany. Zdecydowanie nie uważają się przeto za monofizytów, ale też nie przyznają w pełni racji nauce Kościoła katolickiego, a przyczynę różnic poglądów upatrują w odmiennej interpretacji tekstów kanonicznych, nicejskiego Credo i formuły wyznania wiary, opracowanej przez patriarchę Cyryla Aleksandryjskiego (Frend, 1972; Girgis, 1962; Gregorios, Lazareth i Nissiotis, 1981; Luce, 1920; Nichols, 2010). 
Kopt (Bourguet, 1991; Gabra, 1999). Obecnie Koptyjski Kościół Prawosławny liczy ok. 8 mln wiernych (tj. 10\% ludności Egiptu), a na jego czele stoi od 2012 r. rezydujący w Kairze Patriarcha Tawardos II. Koptyjski Kościół Katolicki pod przewodnictwem patriarchy Ibraima Izaaka Sidraka (od 2013 r.) pozostaje zasadniczo w diasporze rozsianej po krajach Europy, USA oraz Australii i liczy ok. 200 tys. wiernych (Chaillot, 2005; Gaselee, 1925; Meinardus, 2002; Roberson, 2005).

Niezależnie od tego, do którego z tych dwóch Kościołów dany wierny przynależy, Koptowie od wieków z równym zapałem bronią swojej tożsamości i odrębności, tak kulturowej, jak i religijnej. Będąc w Egipcie, można ich zatem odróżnić od islamskiej większości po imieniu (jeśli oczywiście takowe poznamy), które będzie staroegipskie, europejskie, chrześcijańskie, ale nigdy muzułmańskie; noszonej złotej biżuterii z motywami chrześcijańskimi; zaś w przypadku kobiet - po odsłoniętych włosach. A wreszcie po tatuażu.

\section{Tatuaż i jego funkcja}

Omawiając zagadnienie historii tatuażu koptyjskiego i odgrywanej przez niego roli, niezbędne będzie sięgnięcie po definicję tatuażu jako takiego zjawiska znanego przecież od pradziejów i niezwykle bogatego w swej warstwie znaczeniowej. Choć, po prawdzie, encyklopedyczne definicje rzeczywistość tę znacznie spłycają. Oto bowiem odnajdujemy takie np. wyjaśnienie tegoż terminu: „trwały rysunek, napis na skórze człowieka, wykonany za pomocą nakłuwania lub nacinania skóry i zapuszczania nakłuć farbą; rozpowszechniony wśród niektórych plemion pierwotnych, zapożyczonych od nich przez marynarzy, spotykany obecnie w niektórych środowiskach (marynarskim, więziennym)" (Tokarski, 1980, s. 747). W innych słownikowych definicjach pojawia się natomiast ogólne nadmienienie o „funkcji dekoracyjnej i społecznej” (Brzozowska, 2002, s. 592; Kalisiewicz, 1996, s. 320), „ozdobie ciała” czy „rodzaju amuletu ochronnego" (Dyczkowski, 1998, s. 1753).

Aby zaś uzmysłowić sobie wielorakość i bogactwo roli, jakie tatuaż odgrywał lub odgrywa w różnych warstwach społecznych i rejonach geograficznych oraz na różnych etapach historii, wystarczy przywołać choćby typologię autorstwa Macieja Szaszkiewicza (1997), który wymienia następujące jego funkcje:

a. magiczno-religijne - tatuaże apotropaiczne lub będące symbolem wyznawanej wiary;

b. militarne - u plemion prymitywnych to swoiste odznaczenia potwierdzające liczbę zwycięstw odniesionych w walce czy po prostu 
oznaka przynależności do grupy wojowników; sam tatuaż bywa również traktowany jako rodzaj bojowej ochrony lub mistycznej broni;

c. socjalne - tatuaże wskazujące na przynależność rodową, plemienną, kastową; ponadto symbol pozycji społecznej czy stanu cywilnego, a nawet dowód zaciagnniętego długu i cennik świadczonych usług;

d. seksualne - symbol osiagnnięcia wieku dojrzałości płciowej, a także czynnik wspomagający pobudzenie erotyczne; w wyjątkowych przypadkach tatuaż taki uchodzi równiė̇ za skuteczny środek antykoncepcyjny;

e. estetyczne - element upiększający i ozdoba ciała;

f. represyjno-ostrzegawcze - tatuaż stanowiący fizyczne znamię, stosowane - od starożytności - dla piętnowania niebezpiecznych przestępców, uciekinierów czy nierządnic; zaś w XX-wiecznych systemach totalitarnych znak identyfikujący więźniów przetrzymywanych w obozach;

g. patriotyczne - tatuaże często przybierające postać sentencji i haseł propagandowych wyrażających sprzeciw wobec ustroju i władz lub wprost przeciwnie - oddanie wobec własnego kraju, regionu, sekty;

h. psychologiczne - symbol uczuć, postaw i poglądów, cech psychicznych oraz zainteresowań i umiejętności danej osoby; często to znaki upamiętniające ważne wydarzenia życiowe;

i. profilaktyczne - tatuaż z oznaczeniem grupy krwi stosowany często w armiach, np. członkowie SS wykonywali takie znaki pod lewą pachą, na ramieniu lub na podniebieniu (obok podwójnej runy sig - symbolu SS lub swastyki).

Przedstawiona powyżej typologia będzie stanowić punkt wyjścia dla dalszych rozważań nad rolą tatuażu w koptyjskim kręgu kulturowym. Dla zarysowania jednak pełniejszego tła historycznego omawianego zagadnienia należy także przytoczyć podstawowe informacje dotyczące występowania i znaczenia tegoż zjawiska w Egipcie przedchrześcijańskim. A fakt, iż technikę tatuażu znano i praktykowano nad Nilem już co najmniej cztery tysiące lat temu, potwierdzają różnorodne świadectwa archeologiczne. Są to m.in. mumie, na których skórze przetrwały wytatuowane wzory. Dokumentowały one przyżyciowe doświadczenia osoby zmarłej bądź stanowiły pozostałość zabiegów magiczno-leczniczych, jakim była poddawana ${ }^{3}$.

3 Dla przykładu, w okolicy Teb znaleziono mumię kobiecą z III tys. a.Ch., z której tatuaży wyczytać można informację o małżeństwie, jakie zawarła z sąsiednim księciem, o narodzinach jej kolejnych dzieci i śmierci osób jej bliskich. Z kolei mumia tebańskiej kapłanki bogini Hathor o imieniu Ameut (datowana na II tys. a.Ch.) posiadała wytatuowane na ramionach i udach równoległe linie oraz eliptyczne kształty na brzuchu, prawdopodobnie o przeznaczeniu medycznym. Dwa zmumifikowane ciała tancerek, odkryte w 1922 r. pod świątynią Hatszepsut w Deir el-Bahari, noszą 
Wskazać można również polichromowane figurki kobiece lub przedstawienia postaci zachowane na ścianach obiektów sepulkralnych, które jednoznacznie świadczą, iż tatuaże były noszone już w okresie Starego Państwa (Nowak, [2011]). Mariusz Snopek (2010) podkreśla natomiast fakt, iż archeolodzy odnaleźli w wyposażeniu przedchrześcijańskich pochówków egipskich brązowe igły służące do przeprowadzania samego procesu tatuowania.

Reasumując - w starożytnym Egipcie tatuaż był znany i szczególnie popularny wśród kobiet, niezależnie od ich statusu społecznego: królewskich konkubin, kapłanek, prostytutek. Miał je chronić w trudnym czasie ciąży i narodzin czy strzec przed chorobami wenerycznymi. Należy jednak pamiętać, iż służył także naznaczaniu przedstawicieli stanu niewolniczego.

Inną kwestią pozostaje fakt, jak do tego - pogańskiego w swych korzeniach - obyczaju odnosili się Egipcjanie, którzy przyjęli z czasem Dobrą Nowinę. Zasadniczo możliwości były dwie - odrzucenie lub synkretyzm. Wybór był zaś uzależniony od tego, jak chrześcijaństwo - a ściślej pisma kanoniczne, patrystyczne, synodalne czy papieskie - wypowiadały się na temat takiej formy ingerencji w wizerunek człowieka.

\section{Stosunek chrześcijaństwa do tatuażu na przestrzeni wieków}

Już Pięcioksiag wyraźnie zabraniał wykonywania tatuaży: „Nie będziecie sobie robili nacięć na ciele za człowieka zmarłego, nie będziecie się też tatuować. Jam jest Jahwe” (Kpł 19,28). W podobnym duchu wypowiadał się i św. Piotr: „Niech ozdobą ich nie będzie to, co zewnętrzne: piękne uczesanie, obwieszanie się złotem ani też wyszukany strój sukni. Niech będzie nią niezniszczalne wnętrze człowieka, w którym kryje się łagodne serce i duch spokojny, tak wysoko ceniony przez Boga" (1 P 3,3-4). Zarówno więc Stary, jak i Nowy Testament zalecały unikania tatuaży, poczytując je za świadectwo działania demonicznego. Jako swoistą - choć niepewną - antytezę z ksiąg kanonicznych można jednak przytoczyć słowa św. Pawła, który pisał: „Odtąd niech już nikt nie sprawia mi przykrości: przecież ja na ciele swoim noszę blizny, znamię przynależności do Jezusa” (Ga 6,17). Wątpliwości budzi tu jednak fakt, czy owo pawłowe „znamię” należy utożsamiać z tatuażem sensu stricto, czy raczej rozumieć je jako znak duchowy lub odwołanie do blizn, jakie pozostały na ciele apostoła po razach znoszonych przez niego dla Imienia Pańskiego.

natomiast tatuaże przedstawiające wizerunek bożka Beza - opiekuna kobiet (Bojarska i Trzaska, 2000; Czerni, 1997; Klonowska, Wiciński, Wołkowiecki i Żak, 2017; Nowak, [2011]). 
Jednocześnie świadectwa ojców Kościoła wskazują, iż już pierwsi naśladowcy Chrystusa - kontynuując swoje dotychczasowe zwyczaje nosili na dłoniach lub czołach trwałe rysunki symbolizujące osobę Zbawiciela (np. jagnię, rybę, chryzmon) i uznawali je za element integrujący wspólnotę wiernych wobec prześladowań (Fleming, 2001; Gilbert, 2000; Snopek, 2010). Wraz z zaakceptowaniem chrześcijaństwa w Imperium Romanum pojawiły się jednak oficjalne edykty cesarskie - wydawane przez władcę, który jako pontifex maximus ciągle czuł się odpowiedzialny za sprawy religijne - zakazujące tatuowania, szczególnie twarzy. Za uzasadnienie posłużył tu fakt, iż człowiek został stworzony na podobieństwo Boga, a zatem jego oblicze jest odwzorowaniem oblicza boskiego i nie wolno go zniekształcać (Bojarska i Trzaska, 2000).

Jeszcze inaczej kwestia ta wyglądała w wiekach średnich na terenach byłego Barbaricum (np. w Szkocji), gdzie dochodziło do przenikania się motywów tatuaży chrześcijańskich i stosowanych przez autochtoniczne ludy pogańskie. Notabene pierwszy opis europejskiego zabiegu zwanego po łacinie punctum pozostawił ok. 600 r. bp Izydor z Sewilli (560-636), notując, iż „Piktowie mieli zgodnie ze swoim imieniem obyczaj ozdabiania ciał obrazkami. Zniekształcali oni ciała, nakłuwając igłami skórę i wcierając w nią sok pewnej rośliny” (Wagner, 2002, s. 26). Wobec takiego stanu rzeczy na saksońskim synodzie w Calcuth (787 r.) z inspiracji papieża Hadriana I (700-795) potępiono zwyczaj tatuowania jako zabiegu zagrażającego zbawieniu duszy. Zaś kolejni biskupi Rzymu podtrzymywali tę decyzję, dodając, iż proces ów niszczy podobieństwo Boże w człowieku i kojarzony jest głównie z marginesem społecznym (Snopek, 2010; Zwoliński, 2006).

Niekonsekwentnie jednak wobec zaleceń hierarchów kościelnych rycerze wyruszający na kolejne krucjaty nierzadko wykonywali tatuaże w kształcie krzyża. W praktyce tej upatrywali zaś szansę, iż w razie śmierci na ziemi opanowanej przez islam zostaną rozpoznani przez współwyznawców i pochowani zgodnie z obrządkiem chrześcijańskim (Jelski, 1993). W kolejnych wiekach Kościół nie przeciwstawiał się także tatuażom o charakterze religijnym, jakie nosili katoliccy mieszkańcy Bośni i Hercegowiny w dobie zagrożenia tych terenów przez Imperium Osmańskie. Uważano je nawet za środek zabezpieczający posiadacza przed przejściem na muzułmanizm ${ }^{4}$. Nie zabraniano wreszcie wykonywania tatuaży

4 Przy czym badania prowadzone nad tym zagadnieniem pokazały, że zwyczaj ów najprawdopodobniej sięga czasów przedchrześcijańskich i nawiązuje jeszcze do tradycji trako-illyryjskiej. Wskazują na to okoliczności i obyczaje związane z tym obrzędem. Zwyczajowo bowiem wykonywano go w okolicach 19 marca, tj. liturgicznego wspomnienia św. Józefa, ale też dnia przywitania wiosny. Tatuażystkami były starsze i doświadczone kobiety, zaś tatuowanymi - młodzieńcy w okresie dojrzewania. Wreszcie sam tatuaż niekoniecznie posiadał kształt krzyża, lecz sięgano również po wizerunek księżyca czy słońca (Nowak, [2011]; Snopek, 2010). 
przedstawiających symbole chrześcijańskie pielgrzymom, którzy wracali z Ziemi Świętej. Przywozili więc oni na swych ciałach - jako niezatarte świadectwa wiary - wizerunki Gwiazdy Betlejemskiej, krzyża jerozolimskiego czy scen z życia Jezusa (zwł. pasyjnych). Praktyka ta nieobca była nawet przedstawicielom wyższych warstw społecznych, np. król Anglii Jerzy V (1865-1936) podczas pobytu w Jerozolimie w 1881 r. wytatuował sobie Gwiazdę Betlejemską (Jelski, 1993). Z kolei dziesięć lat później opisano fakt, iż od połowy XIX w. również wierni przybywający do włoskiej miejscowości Loretto korzystali tam z możliwości wykonania tatuaży nawiązujących do symboliki maryjnej (Snopek, 2010).

W swej dwudziestowiecznej historii Kościół miał zatem do tej formy naznaczania ciała stosunek ambiwalentny - ewidentnie uzależniony od miejsca, czasu i okoliczności, w których rzeczone praktyki stosowano. W przypadku zaś Koptów, zarówno w okresie przed inwazją islamską, jak i po niej, mamy do czynienia z niezaprzeczenie złożoną sytuacją społeczno-religijną.

\section{Tatuaż koptyjski - geneza i praktyka współczesna}

Opisane pokrótce powyżej położenie rdzennych mieszkańców Egiptu w dobie dominacji rzymskiej uzasadniało ich silnie zakorzenioną niechęć do większości przejawów tradycji hellenistycznej. Tym wyraźniej zaznaczali oni swą odrębność kulturową, która z czasem zaczęła oznaczać mocne przywiązanie do religii chrześcijańskiej i swoistą endogamię społeczną, wymuszoną już nie tylko sytuacją prawną, ale również własną wolą Koptów. Każde też panowanie inne niż rzymskie wydawało im się lepsze. Stąd w 619 r. stanęli po stronie sasanidzkiej Persji. I choć Herakliusz dekadę później odzyskał Egipt, to po kolejnych 11 latach ludność koptyjska opowiedziała się przeciwko Rzymowi, a po stronie Arabów (Atiya, 1978).

Wkrótce jednak okazało się, że nowa - trwająca de facto do dzisiaj dominacja islamska jeszcze silniej ugruntowała hermetyczny charakter społeczeństwa koptyjskiego i postawiła jego członków w sytuacji - mniej lub bardziej nasilonego, ale niemal permanentnego - prześladowania z powodów religijnych. Arabscy najeźdźcy stopniowo dążyli bowiem do wyrugowania w Egipcie zarówno religii chrześcijańskiej, jak i języka koptyjskiego. Oporni byli stygmatyzowani przez nakaz noszenia na szyi ciężkiego, pięciofuntowego drewnianego krzyża. I właśnie w tej formie piętnowania część badaczy upatruje źródło trwającego do dziś zwyczaju wykonywania przez Koptów tatuaży w kształcie krzyża na wewnętrznej stronie przegubu prawej dłoni i datuje jego początki na wiek VII. Inni zaś wiążą to zjawisko z rozbudowanym środowiskiem mnichów 
egipskich i przesuwają moment jego powstania na VIII stulecie (Bourguet, 1991) ${ }^{5}$.

Współcześnie tatuowane są osoby w różnym wieku, poczynając już od kilkumiesięcznych niemowląt, w których imieniu decyzję tę podejmują oczywiście rodzice. Nierzadko jednak osoby takie później świadomie i dobrowolnie odnawiają ów znak (Stene, 1997). Są jednak i Koptowie, którym nie wykonano tatuażu w dzieciństwie i którzy czekają z tym aktem na ważne wydarzenie życiowe. Bywa też i odwrotnie - wykonanie tatuażu jest następstwem jakiegoś głębokiego przeżycia. Często chodzi tu o moment odbycia pielgrzymki do Jerozolimy lub innego ważnego sanktuarium, nierzadko również łączy się ze specjalnym dniem, np. Wielkanocą czy wspomnieniem Matki Bożej lub jakiegoś konkretnego świętego patrona ${ }^{6}$.

Stąd też w dni większych świąt i odpustów przy egipskich centrach pielgrzymkowych rozkładane są stoiska przenośnych zakładów tatuażu religijnego. Ich ofertę prezentuje często wywieszona tablica z ponumerowanymi wzorami. Koszt takiej usługi zaczyna się od równowartości 1 euro. Siłą rzeczy stopień zachowania higieny podczas wielu wykonywanych w ten sposób zabiegów znacznie odbiega od europejskich standardów.

Istnieją jednak i zakłady o długiej tradycji, w których funkcja tatuażysty traktowana jest niemal jak powołanie i przechodzi z pokolenia na pokolenie. Za przykład o wyjątkowym charakterze może tu posłużyć rodzina Razzouk, która działa w Jerozolimie od 700 lat i posiada tam obecnie zakład z prawdziwego zdarzenia. Za współczesnego nestora rodu uchodzi Yacoub Razzouk (zwany też po prostu Tatuażystą), który jako pierwszy na tym terenie zastosował elektryczną maszynkę do tatuażu

5 Paradoksalnie władca fatymidzki - kalif Al-Hakim (985-1021) - który wymyślił ten rodzaj stygmatyzacji chrześcijan i zasłynął również z okrucieństwa wobec Żydów, pod koniec swego panowania dostał się pod wpływy mnichów pachomiańskich. Ostatecznie jednak opowiedział się za izmaelicką doktryną sekty druzów, skutkiem czego ogłosił własną deifikację jako nowego wcielenia Allacha (Atiya, 1978).

6 Szczególnie często tatuaże religijne wykonywane są przy okazji siedmiu tzw. świąt większych Ortodoksyjnego Kościoła Koptyjskiego (tj. Bożego Narodzenia - 7 stycznia/29 Kiyahk, Objawienia Pańskiego - 19 stycznia/11 Tuba, Zwiastowania - 7 kwietnia/29 Baramhat, Niedzieli Palmowej, Wielkanocy, Wniebowstąpienia i Zesłania Ducha Św.) Niemniej do aktu tego może dojść także podczas któregoś z siedmiu świąt mniejszych, jakie uwzględnia koptyjski kalendarz liturgiczny (tj. Obrzezania Pańskiego - 14 stycznia/6 Tuba, Cudu podczas Ślubu w Kanie Galilejskiej - 21 stycznia/13 Tuba, Ofiarowania Jezusa w Świątyni - 15 luty/8 Amshir, Wielkiego Czwartku, Niedzieli Tomaszowej - pierwszej niedzieli po Wielkanocy, Wejścia Świętej Rodziny do Egiptu - 1 czerwca/24 Bashans i Przemienienia Pańskiego - 19 sierpnia/13 Misra). Oprócz tego dobrymi momentami są także obchody liturgiczne związane z dziejami relikwii Krzyża Pańskiego, tj. święto jego odnalezienia przez cesarzową Helenę w 326 r. (27 września/17 Tut) oraz przywiezienia Krzyża przez cesarza Herakliusza z Persji do Konstantynopola w 628 r. (19 marca/10 Baramhat) (Chaillot, 2005). 
(zasilaną początkowo z akumulatora samochodowego) i użył kolorowego tuszu (Carswell, 1968; Razzouk, 2020).

Wskazać można i inne różnice, jakie zachodzą w technice wykonywania tatuaży koptyjskich między terenami Egiptu i diasporą jerozolimską. W pierwszym przypadku tatuażyści zazwyczaj kopiują z grubsza rysunek wybrany przez klienta z prezentowanej oferty lub wręcz komponują go na bieżąco wprost na skórze osoby tatuowanej. Z kolei w Jerozolimie stosuje się rzeźbione w drewnie stemple, dzięki którym pożądany rysunek kalkowany jest najpierw na skórę klienta i tworzy wzór, wzdłuż którego pracuje później tatuażysta. Przy czym szanujące się zakłady dysponują zazwyczaj ponad setką stempli z różnymi przedstawieniami (Grira, 2010; Meinardus, 2002).

Współcześnie w Jerozolimie niemal wyłącznie używa się elektrycznych maszynek do tatuażu wstrzykujących tusz pod skórę. Jednakże w Górnym Egipcie ciągle jeszcze można znaleźć miejsca, gdzie stosowana jest tzw. stara metoda. Jej zwolennicy posługują się zestawem powiązanych ze sobą igieł (najczęściej siedmiu), którymi nakłuwają skórę w wybrany wzór. Następnie zaś pokrywają ją warstwą pigmentu - stanowiącego mieszankę sadzy, oliwy i wody - dzięki czemu wnika on w nakłute miejsca (Muyser, 1952).

W przypadku klasycznego tatuażu - zwłaszcza wykonywanego u dzieci - jest to zazwyczaj niewielki równoramienny krzyż koptyjski o wymiarach około jednego centymetra kwadratowego ${ }^{7}$. Jego umieszczenie na wewnętrznej stronie prawego nadgarstka daje możliwość ukrycia w zależności od potrzeby i okoliczności.

Inne popularne wzory można ująć w kilka typów:

7 Motyw takiego właśnie równoramiennego krzyża o rozszerzających się końcach wyjątkowo często pojawiał się już w starożytnej sztuce koptyjskiej, np. na szyi pełnopostaciowego przedstawienia kobiety ze steli grobowej z IV stulecia (najprawdopodobniej z El Ashumein); w zwieńczeniu rzeźbionego tympanonu z Sohag z IV w., gdzie krzyż ów - umieszczony w wieńcu laurowym podtrzymywany jest przez dwóch efebów, czy na XII-wiecznej drogocennej, srebrnej oprawie ewangeliarza z kościoła Dziewicy Maryi (Qasriat Al-Rihan). Często występował on jako dekoracja kapiteli kolumn świątynnych (np. z Bawit), a także jako motyw umieszczony w centrum ozdobnej niszy-konchy w tympanonach lub zwieńczeniach małej architektury kościelnej (np. na ambonie z klasztoru św. Jeremiasza w Sakkarze z VI/VII w., tympanonach z kościoła w Denderah z IV w. czy Białego Klasztoru w Sohag) (Atalla, [1989]; Badawy, 1949; 1978; Bourguet, 1991; Coquin, 1974; Effenberger, 1975; Gabra, 1999; Strzygowski, 1904; Wessel, 1966). We wczesnej twórczości Koptów równie często występuje także schrystianizowany pogański krzyż ankh (łac. crux ansata), czyli tzw. krzyż z pętelką. Wywodzi się on z hieroglificznego znaku oznaczającego „wiązanie sandałów”; a w okresie pogańskim symbolizował życie, zaś trzymany przez bóstwa egipskie - życie wieczne (Bourguet, 1991; Cramer, 1955; Forstner, 1990; Kamil, 1987). Nierzadko zaś obie te formy krzyża łączono w kompozycji dekoracyjnej jednego obiektu, np. na nietypowej poziomej steli nagrobnej z VI/VII w., jaka znajduje się w zbiorach Koptyjskiego Muzeum w Kairze (sygn. 4302) czy na innym zabytku o takim samym charakterze, oznakowanym przez kairskich muzealników sygn. 8585 (Atalla, [1989]; Gabra, 1999; Simaika, 1937). 
a. sceny biblijne, np.: Zwiastowanie, Boże Narodzenie, Ostatnia Wieczerza, Ukrzyżowanie, Zmartwychwstanie ${ }^{8}$;

b. przedstawienia maryjne, np.: Madonna z Dzieciątkiem ${ }^{9}$;

c. święci i aniołowie, np.: Michał Archaniol ${ }^{10}$, Anioł Apokalipsy ${ }^{11}$, św. Damiana ${ }^{12}$, św. Jerzy zabijający smoka ${ }^{13}$;

8 Zbiór ikon z przedstawieniami wymienionych scen biblijnych, które stanowią często wzór dla stempli tatuażystów, znajduje się w kairskim kościele św. Sergiusza (Abu Serga). Najwcześniejsze partie tejże świątyni datowane są na V stulecie; a według lokalnej tradycji została ona wzniesiona nad jaskinią, w której schroniła się Święta Rodzina podczas ucieczki przed gniewem Heroda (Kamil, 1987). Rzecz jasna sceny te pojawiają się w sztuce koptyjskiej wielokrotnie, np. datowane na VI w., ale nawiązujące kompozycyjnie jeszcze do staroegipskiej zasady odrzutowania przedstawienie Zwiastowania ukazano na polichromowanej płaskorzeźbie drewnianej (obecnie w zbiorach Luwru); zaś z absydy kościoła El-Adra w Deir es-Suryani pochodzą XI-wieczne malowidła wyobrażające Zwiastowanie i Boże Narodzenie (Bourguet, 1991).

9 Chodzi tu o wizerunek siedzącej Maryi, która trzyma na kolanach Dzieciątko Jezus. Przypomina on zatem ikony w typie Hodegetrii lub Eleusy. Ze względu jednak na fakt, iż Matka Boża przedstawiana bywa także na tronie, który flankują postaci aniołów lub apostołów, można również wskazywać na analogię z ikonami typu Nikopoia (Pokorzyna, 2001; Smykowska, 2002; Sprutta, 2008a, 2008b). Wyobrażenie to jest Koptom szczególnie bliskie, stąd jego częsta obecność w sztuce egipskich chrześcijan, np. fresk z klasztoru św. Apolla w Bawit (datowany na VI/VII w.), kamienne VI-wieczne rzeźbione stele ze zbiorów Muzeum Koptyjskiego w Kairze (sygn. 8003, 8006) czy malowidło na jednej ze ścian unikatowej, IV-wiecznej, drewnianej arki - tj. skrzynki w kształcie prostopadłościanu przeznaczonej do przechowywania kielicha mszalnego do czasu Komunii św. - z kairskiego kościoła św. Sergiusza (Atalla, [1989]; Bourguet, 1991; Deneuve, 1970; Wessel, 1954/55).

10 Michał Archanioł - uważany przez Koptów za ich szczególnego opiekuna - otaczany był i jest nadal w Egipcie szczególnym kultem. Świadczy o tym choćby fakt, iż - jako jedynego spośród archaniołów - liturgia koptyjska wspomina go w każdy dwunasty dzień miesiąca, a ponadto dedykowano mu dwa osobne święta (19 czerwca/12 Ba'una oraz 21 listopada/12 Hatur). Ze względu zaś na rolę, jaka przypisana została św. Michałowi w apokaliptycznej wizji Sądu Ostatecznego, początkowo widziano w nim schrystianizowaną wersję pogańskiego boga mądrości Thota, odpowiedzialnego za odnotowywanie wyniku psychostazji podczas Sądu Ozyrysa. Stąd też częste przedstawienia Michała Archanioła, np. na VII-wiecznej płaskorzeźbie tympanonu z El Minya, gdzie otacza go stadko owiec - symbol żyjących lub już zmarłych wiernych Egipcjan, których niebieski patron ochrania i strzeże (Chaillot, 2005; Kamil, 1987; Wessel, 1966).

11 Wizerunki aniołów o różnych funkcjach obecne są już we wczesnych przykładach sztuki koptyjskiej, np. na płycie reliefowej z IV w. dwie uskrzydlone istoty towarzyszą Chrystusowi wstępującemu do nieba prosto z Golgoty, zgodnie z dosłownym odczytaniem nowotestamentalnych fragmentów Mk 16,19; Łk 24,51 i Dz 1,9. (Wessel, 1966, 1963).

12 Św. Damiana według koptyjskiej tradycji była córką zarządcy obszaru północnej Delty i poniosła śmierć męczeńską za wiarę wraz z czterdziestoma towarzyszkami podczas prześladowań Dioklecjana; jej wspomnienie w liturgii Kościoła koptyjskiego przypada na dzień 21 stycznia/13 Tuba (Chaillot, 2005; Kamil, 1987; Meinardus, 1969).

13 W podobnym ujęciu - jako konny rycerz uśmiercający smoka - przedstawiany jest także św. Teodor (zwany również Amir Tadrus) z Shutb niedaleko Asyut (czczony przez Koptów 27 lipca/20 Abib). Przy czym badacze zwracają również uwagę na podobieństwo tej sceny do pogańskiego przedstawienia boga Horusa przeszywającego włócznią Seta - swego wroga, a zarazem w jednej osobie stryja i wuja (Chaillot, 2005; Kamil, 1987). 
d. przedstawienia symboliczne: krzyż ${ }^{14}$, krzyż jerozolimski ${ }^{15}$, ptak $^{16}$, orzet $^{17}$;

e. motywy epigraficzne, np.: imię Jezusa ${ }^{18}$, cytat biblijny.

Przy czym co do wyboru tatuowanego motywu zauważalne są pewne prawidłowości. Kobiety z reguły wolą bowiem tatuaże niewielkie, takie jak klasyczny koptyjski krzyż czy imię Jezusa. Z kolei wśród mężczyzn często trafiają się zwolennicy tatuaży o znacznych rozmiarach, np. pełnopostaciowego kolorowego przedstawienia Chrystusa, Maryi czy świętego patrona, a nawet całych scen biblijnych. Z konieczności więc tego typu motyw wykonywany jest wówczas na części lub wręcz całym ramieniu. Nierzadko też Koptowie płci męskiej posiadają więcej niż jeden tatuaż.

\section{Znaczenie tatuażu religijnego w środowisku koptyjskim}

W dobie nasilonych obecnie ataków islamskich na wyznawców chrześcijaństwa omówione tatuaże służą Koptom - podobnie jak niegdyś ich

14 Zob. przyp. nr 7.

15 Krzyż jerozolimski to krzyż równoramienny z poprzecznymi zakończeniami ramion i z czterema mniejszymi krzyżykami umieszczonymi między nimi. W tradycji chrześcijańskiej ma on symbolizować pięć ran zadanych Chrystusowi albo też Mesjasza i cztery Ewangelie. Co zrozumiałe, najczęściej tatuaż o takim kształcie wykonywany bywa przy okazji pielgrzymki do Jerozolimy. Przy czym często Koptowie dodają nad wizerunkiem krzyża trzy korony, zazwyczaj tłumaczone jako symbole Trójcy Świętej (Forstner, 1990).

16 Przedstawienie ptaka nieobce było i przedchrześcijańskiej sztuce egipskiej, w której symbolizowało m.in. nieśmiertelny element duszy ludzkiej ba (Kamil, 1987). Natomiast w manuskryptach koptyjskich wizerunki ornitomorficzne stanowity niezwykle popularny motyw dekoracyjny, który umieszczano na marginesach tekstów lub wplatano w inicjał rozpoczynający daną stronę czy akapit (najczęściej wykorzystywano w tym celu literę alpha). Całą serię przykładów tego typu, niezwykle barwnych i cechujących się specyficzną smukłością, wyobrażeń ptaków zamieszczonych w manuskryptach ze zbiorów Biblioteki Muzeum Koptyjskiego w Kairze przedstawia Nabil Selim Atalla (2000).

17 Orzeł - identyfikowany w podbitym przez Rzym Egipcie ze znakiem zwycięskich legionów cesarskich - z czasem nabrał także charakteru chrześcijańskiego i jako taki pojawiał się w wytworach sztuki i rzemiosła. Dla przykładu: na fragmencie draperii ściennej z V/VI w. widnieje on z wysoko postawionymi skrzydłami, głową opromienioną nimbem, liściem bluszczu w dziobie i greckim krzyżem zawieszonym na szyi (Wessel, 1963; 1966). Podobne wizerunki znane są także z licznych koptyjskich kamiennych steli nagrobnych (np. z Assiut). Na zabytkach tych orzeł przedstawiany jest z reguly z głową zwróconą w bok i z medalionem (bulla) na szyi, czasem również z krzyżem ankh $\mathrm{w}$ dziobie, zaś uniesionymi skrzydłami podtrzymuje wieniec okalający krzyż lub chryzmon (Simaika, 1937). Takie ujęcie - paralelne do zdobień z rzymskich i galijskich sarkofagów - nasuwa skojarzenie z symbolicznym wyrazem tryumfu Chrystusa i chrześcijaństwa (Forstner, 1990).

18 Tatuowane imię Jezusa może zostać wyrażone, wzorem starożytnych skrybów i rzeźbiarzy koptyjskich, za pomocą ligatury E F - iHsous xristos, jak np. na inskrypcji z zabytku o sygn. 8325 ze zbiorów Muzeum Kairskiego (Atalla, [1989]). 
przodkom - do religijnej i etnicznej identyfikacji w zdominowanym przez Arabów państwie. Z tego też względu często przy drzwiach kościołów koptyjskich w Egipcie spotkać można współczesnych ostiariuszy, którzy sprawdzają, czy wchodzący istotnie posiada tatuaż. Zaś część tatuażystów domaga się potwierdzenia religijnej przynależności osoby, która prosi o jego wykonanie.

Znak ten pozwala także na symboliczne zgromadzenie się wiernych wokół krzyża, który ma potężną moc. Jak bowiem przekazuje koptyjska tradycja, gdy św. Antoni Pustelnik rysował go na ziemi, demony drżały. Z tej samej zresztą - apotropaicznej - przyczyny Koptowie nadal malują krzyż na drzwiach swych domów, szczególnie w Środkowym i Górnym Egipcie (Chaillot, 2005; Meinardus, 2002).

Tatuaż ten stanowi zarazem przypomnienie nieustannego błogosławieństwa, jakie spływa na chrześcijan i zobowiązuje ich do wierności wyznawanej wierze. To w mentalności wielu osób również sposób na połączenie się w momencie bólu odczuwanego podczas wykonywania tatuażu ze zbawczym cierpieniem Chrystusa.

Reasumując zatem, tatuaż koptyjski pełni - odwołując się do powyższej typologii M. Szaszkiewicza - funkcję magiczno-religijną (jako symbol wiary), ale i socjalną (jako znak przynależności do diaspory chrześcijańskiej) oraz psychologiczną (jako widoczny wyraz uczuć i postawy religijnej, włącznie z gotowością na śmierć za Chrystusa). Czasem, choć rzadko, pełni także funkcję czysto estetyczno-dekoracyjną.

\section{Podsumowanie}

W ciąu ostatnich kilku lat obserwuje się spadek popularności tatuaży religijnych wśród Koptów. Zanik tego zjawiska występuje zwłaszcza wśród przedstawicieli wykształconych klas wyższych, zamieszkujących egipskie miasta. Często sięgają oni przy tym po substytut w postaci złotego krzyżyka noszonego na szyi. Inaczej jednak jest w górnoegipskich wioskach czy w jerozolimskiej diasporze, gdzie tatuaż nadal stanowi powód do dumy, zaś członkowie zakładu rodziny Razzouk szacują, iż rocznie mają około 200 klientów. Trwałość i głębokie znaczenie tej tradycji dobrze oddaje choćby znana dziecięca piosenka koptyjska, która rozpoczyna się od słów „Jestem chrześcijaninem, chrześcijaninem/ (Popatrz na) tatuaż na mojej ręce!" (Stene, 1997, s. 195, tłum. własne). 


\section{BIBLIOGRAFIA}

Atalla, N.S. [1989]. Coptic Art. t. 2: Sculpture. Architecture. Cairo: Lehnert \& Landrock.

Atalla, N.S. (2000). Illustrations from Coptic Manuscripts. Cairo: Lehnert $\&$ Landrock.

Atiya, A.S. (1978). Historia Kościotów Wschodnich. Tłum. zbiorowe. Warszawa: PAX.

Badawy, A. (1949). L'art copte. Les influences égyptiennes. Cairo: Société Orientale de Publicité Press.

Badawy, A. (1978). Coptic Art and Archeology. The Art of the Christian Egyptians from the Late Antique to the Middle Ages. Cambridge: M.I.T. Press.

Bojarska, R. i Trzaska, D. (2000). Krótka historia tatuażu (cz. 1). TatuażCiato i Sztuka, nr 1, 6-15.

Bourguet du, P. (1991). Sztuka Koptów. Tłum. J. Lipińska. Warszawa: Wydawnictwa Artystyczne i Filmowe.

Brzozowska, R. (red.). (2003). Praktyczny stownik wyrazów obcych. Kraków: Zielona Sowa.

Carswell, J. (1968). Coptic Tattoo Designs. Beirut: American University of Beirut. Chaillot, Ch. (2005). The Coptic Orthodox Church. A Brief Introduction to Its Life and Spirituality. Paris: Inter-Orthodox Dialogue.

Coquin, Ch. (1974). Les édifices chrétiens du Vieux-Caire. T. 1: Bibliographie et topographie historiques. Cairo: Institut Français d'Archéologie Orientale.

Cramer, M. (1955). Das altägyptische Lebenszeichen in christlichen (Koptischen) Ägypten. Eine kultur-und religionsgeschichtliche Stuudie auf archäologischer Grundlage. Wiesbaden: Harrassowitz.

Czerni, K. (1997). Piętno. Polska Sztuka Ludowa. Konteksty. Antropologia Kultury, Etnografia, Sztuka, nr 3-4, 124.

Deneuve, G. (1970). L'Arte Copta. Florence: Sadea.

Desprez, V. (1999). Poczatki monastycyzmu. Dzieje monastycyzmu chrześcijańskiego do Soboru Efeskiego (431). T. 1-2. Tłum. J. Dembska. Kraków: Wydawnictwo Benedyktynów. (Źródta Monastyczne, 22).

Draguet, R. (1949). Les Pères du désert. Paris: Plon.

Drączkowski, F. (1998). Patrologia. Pelplin-Lublin: Bernardinum.

Dyczkowski, A. (red.). (1998). Nowy leksykon PWN. Warszawa: Wydawnictwo Naukowe PWN.

Effenberger, A. (1975). Koptische Kunst. Ägypten in spätantiker, byzantinischer und frühislamischer Zeit. Leipzig: Koehler und Amelang.

Farid, S.W. (1965). The Flight into Egypt. Cairo: Youssef Abdalla.

Fleming, J. (2001). Graffiti and the Writing Arts of Early Modern England. Philadelphia: University of Pennsylvania Press.

Forstner, D. (1990). Świat symboliki chrześcijańskiej. Tłum. W. Zakrzewska, P. Pachciarek i R. Turzyński. Warszawa: PAX. 
Frend, W.H.G. (1972). The Rise of the Monophysite Movement. Cambridge: University Press.

Gabra, G. (1999). Cairo. The Coptic Museum and Old Churches. Cairo: Longman. Gaselee, S. (1925). The Unitates and their Rites. London: MacMillan.

Gilbert, S. (2000). The Tattoo History Source Book. An Anthology of Historical Records of Tattooing Throughout the Word. New York: Juno Books.

Girgis, W.A. (1962). The Christological Teaching of the Non-Chalcedonian Churches. Cairo: The American University at Cairo Press.

Gregorios, P., Lazareth, W.H. i Nissiotis, N.A. (red.). (1981). Does Chalcedon Divide or Unite? Towards Convergence in Orthodox Christology. Geneva: World Council of Churches.

Grira, S. (2010). Les chrétiens égyptiens se font tatouer leur foi. Pozyskano z: https://observers.france24.com/fr/20101116-egypte-chretiens-font-tatouer -leur-foi (dostęp: 28.07.2020).

Hamilton, A. (2006). The Copts and the West 1439-1922. The European Discovery of the Egyptian Church. Oxford: Oxford University Press.

Jelski, A. (1993). Tatuaz. Warszawa: Wydawnictwo Alfa.

Kalisiewicz, D. (red.). (1996). Nowa encyklopedia powszechna PWN. T. 6. Warszawa: Wydawnictwo Naukowe PWN.

Kamil, J. (1987). Coptic Egypt. History and Guide. Cairo: The American University at Cairo Press.

Klonowska, J., Wiciński, M., Wołkowiecki, M. i Żak, J. (2017). Historyczne i współczesne społeczno-kulturowe funkcje tatuażu. Kosmetologia Estetyczna, nr 5, 513-520.

Lambelet, E. (red.). (1993). The Escape to Egipt According to Coptic Tradition. Cairo: Lehnert \& Landrock.

Lefort, L.Th. (1943). Les vies coptes de saint Pachôme et ses premiers successeurs. Louvain: Bureaux du Muséon.

Luce, A.A. (1920). Monophysitism, Past and Present. A Study in Christology. London: MacMillan.

Meinardus, O. (1961). Monks and Monasteries of the Egyptian Deserts. Cairo: The American University at Cairo Press.

Meinardus, O. (1963). In the Steps of the Holy Family from Bethlehem to Upper Egypt. Cairo: Dar al-Maaref.

Meinardus, O. (1969). A Critical Study on the Cult of Sitt Dimiana and Her Forty Virgins. Orientalia Suecana, nr 18, 45-68.

Meinardus, O. (2002). Two Thousand Years of Coptic Christianity. Cairo: The American University at Cairo Press.

Michalski, M. (1975). Antologia literatury patrystycznej. T. 1. Warszawa: PAX.

Muyser, J. (1952). Survivance de tatouage Chrétien en Egypte. Cahiers Coptes, nr 2, 11-23.

Nichols, A. (2010). Rome and the Eastern Churches. San Francisco: Ignatius Press. 
Nowak, G. [2011]. Sztuka tatuażu. Płock: Muzeum Mazowieckie.

Pokorzyna, E. (2001). Stownik terminologiczny wyposazenia światyń obrzadku wschodniego z przydatkiem ikon maryjnych. Warszawa: Wydawnictwo DiG.

Razzouk, W. (2020). Razzouk Tattoo - our history. Pozyskano z: http://razzouktattoo.com/ (dostęp: 27.07.2020).

Roberson, R.G. (2005). Chrześcijańskie Kościoty Wschodnie. Tłum. K. Bielawski i D. Mionskowska. Kraków: Wydawnictwo Homini.

Simaika, M.H. (1937). Guide sommaire du museé copte. Cairo: Imprimerie nationale.

Smykowska, E. (2002). Ikona. Maty stownik. Warszawa: Verbinum.

Snopek, M. (2010). Tatuaz. Element wspótczesnej kultury. Toruń: Wydawnictwo Adam Marszałek.

Sprutta, J. (2008a). Ikona maryjna typu Eleusa. Salvatoris Mater, nr 10, $105-124$.

Sprutta, J. (2008b). Ikona Matki Bożej Hodegetrii. Salvatoris Mater, nr 10, $125-152$.

Stene, N. (1997). Becoming a Copt. The Integration of Coptic Children into the Church Community. W: N. v. Doorn-Harder i K. Vogt (red.), Between Desert and City. The Coptic Ortodox Church Today. Oslo: Novus Vorlag, 190-211.

Strzygowski, J. (1904). Koptische Kunst. Catalogue générale des antiquités égyptiennes du Museé du Caire. Vienna: Imprimerie Adolf Holzhausen.

Szaszkiewicz, M. (1997). Tajemnice grypserki. Kraków: Wydawnictwo Instytutu Ekspertyz Sądowych.

Tokarski, J. (red.). (1980). Stownik wyrazów obcych PWN. Warszawa: PWN.

Wagner, P. (2002). Pictish Warrior AD 297-841. Oxford: Osprey Publishing.

Wessel, K. (1954/55). Eine Grabstele aus Medinet el-Fajoum. Zum Problem der Maria Lactans. Wissensch. Zeitschrift der Humboldt-Universität zu Berlin, nr 4, 149-153.

Wessel, K. (1963). Koptische Kunst. Die Spätantike in Ägypten. Recklinghausen: Verlag Aurel Bongers.

Wessel, K. (1966). Sztuka koptyjska. Tłum. E. Bartniczak, A. Bochnak i J. Ostrowski. Kraków: Muzeum Narodowe.

Zwoliński, A. (2006). Mowa ciała. Gesty, stroje, tatuaze, makijaż... Kraków: Wydawnictwo św. Stanisława.

Joanna Małocha - magister historii i archeologii, doktor nauk humanistycznych oraz licencjonowany archiwista i tutor akademicki. Od 2006 r. zatrudniona na Wydziale Historii i Dziedzictwa Kulturowego Uniwersytetu Papieskiego Jana Pawła II w Krakowie, gdzie prowadzi zajęcia m.in. z języka koptyjskiego i sztuki starożytnego Egiptu. Była również wykładowcą w Instytucie Kulturoznawstwa Bliskiego i Dalekiego Wschodu UJ oraz współpracuje z kieleckim wojskowym Centrum Szkoleń na Potrzeby Sił Pokojowych NATO. 
